\title{
"Det är något jag känner att jag är menad för". En diskursanalytisk studie av nyblivna studenters val att läsa en lärarutbildning
}

\author{
Signild Risenfors och Elin Almér \\ Institutionen för individ och sambälle, Högskolan Väst
}

\begin{abstract}
I följande artikel undersöks vilka diskurser och positioneringar som framträder hos studenter angående deras val att läsa en lärarutbildning. Positioneringar handlar i denna studie om grad av säkerhet, generalisering och attityd, som här har att göra med känslor och värderingar. Att få syn på diskurserna och positioneringarna är relevant för lärarutbildare för att kunna utveckla adekvata strategier för undervisning inom lärarutbildningen. Emedan tidigare forskning genomlyst motiven med en innehållslig synvinkel presenteras i den här artikeln en motsvarande genomlysning av hur innehållet, det vill säga motiven, faktiskt formuleras. Vi menar att i sättet att formulera motiven finns en problematisk aspekt som lärarutbildare bör bemöta för att undervisningen ska leda till att lärarstudenten får en utbildning som är hållbar över tid i ett samhälle i ständig förändring. Resultatet av den studie vi presenterar visar att studenterna främst uttrycker en social diskurs och positioneringar som förmedlar en syn på lärar- och elevidentiteter som förhållandevis ensidiga. I mötet med ett akademiskt förhållningssätt där perspektivtagande och utveckling står i fokus kan en dylik hållning behöva luckras upp för att ge utrymme för förståelse av kunskapande och undervisningskontexter.
\end{abstract}

Nyckelord: lärarstudenter, utbildningsval, identitet, diskurs, positionering

\section{INLEDNING OCH FORSKNINGSBAKGRUND}

Den breddade rekryteringen till dagens lärarutbildningar har lett till en heterogen studentgrupp som högskoleväsendet ansvarar för ska få en hållbar utbildning. Undervisning med nyblivna högskolestudenter genererar funderingar kring hur man från högskolor och universitet didaktiskt bör möta studenterna där de befinner sig för att på bästa sätt kunna handleda dem genom utbildningen. Det handlar om frågor som rör förkunskaper samt om hur utbildningen ska se ut för att ge studenterna kunskap och förmåga att i sin kommande yrkesroll aktivt medverka i samhällsbygget.

Valet att läsa en lärarutbildning skiljer sig från andra akademiska utbildningar såtillvida att det är ett yrkesval som relaterar till en profession som den sökande har haft erfarenhet av under sin egen skolgång. Dessa egna erfarenheter har gett individen förantaganden om läraryrket (Säll, 2000; Persson, 2009). Tidigare studier har i hög grad satt fokus på studenters motiv till att börja sin högskoleutbildning. I denna studie tar vi istället fasta på studenters förhållningssätt, vilket betyder att vi har större intresse av hur studenterna uttrycker motiven än vilka motiven är.

I flertalet studier redovisas motiven för att utbilda sig i termer av kategorierna intrinsic (inre), extrinsic (yttre) och altruistic (altruistiska) efter Brookhart och Freeman (1992). Inre motiv som intresse av att arbeta med barn eller att tycka om att arbeta med barn är den motivator som hamnar i topp i större enkätstudier i industriländer (Holm, 200I; Calander, 2003), även

*Författarkontakt: signild.risenfors@hv.se

Artiklar och reflektioner är kollegialt granskade. Övriga bidragstyper granskas av redaktionen. Se https://hogreutbildning.se ISSN 2000-7558

(C)2019 Signild Risenfors och Elin Almér. This is an Open Access article distributed under the terms of the Creative Commons AttributionNonCommercial 4.0 International License (https://creativecommons.org/licenses/by-nc/4.0/), allowing third parties to share their work (copy, distribute, transmit) and to adapt it, under the condition that the authors are given credit, that the work is not used for commercial purposes, and that in the event of reuse or distribution, the terms of this license are made clear.

Citation: Risenfors, S. \& Almér, E. (2019) “"Det är något jag känner att jag är menad för". En diskursanalytisk studie av nyblivna studenters val att läsa en lärarutbildning", Högre utbildning, 9(2), 48-59. https://doi.org/10.23865/hu.v9.1317 
om Weiner (1993) också noterade en skillnad beroende på lärarstudenternas socioekonomiska status. Lärarstudenter från en statlig högskola angav i Weiners studie i högre grad yttre skäl än de som läste vid Harvard Graduate School of Education. Lärarstudenter som sätter fokus på att undervisa barn i yngre åldrar uttrycker främst ett omsorgsbehov om barnet och sätter barnet självt i fokus (Holm, 20oI) medan de som inriktar sig mot äldre åldrar har fokus mot elevens eller skolans utveckling (ibid), läraruppdraget (Lilliestam, 20I5) eller de ämnen de ska undervisa i (Younger, Brindley, Pedder \& Hagger, 2004/2007). Bergmark, Lundström, Manderstedt och Palo (20I8) belyser dock vikten av att ta hänsyn till att motiven ofta är multipla och av både inre och yttre karaktär för att kunna skapa en lärarutbildning som borgar för att individen blir kvar i yrket. Lärarstudenternas motiv till att börja en lärarutbildning i relation till deras motivation, självtillit och akademiska engagemang tas upp av Alm, Jungert och Thornberg (20I4) som i sin diskussion lyfter behovet av att tillmötesgå studenternas primära motiv för att få dem att stanna kvar i utbildningen. De föreslår att de pedagogiska möten som sker inom lärarutbildningen ska ha fokus på att bibehålla det engagemang för yrket som studenterna har med sig in i utbildningen.

Att tala om akademisk utbildning som om det vore en homogen institution är inte görbart, men det finns vissa grundläggande, professionella, förhållningssätt som anförs den akademiska verksamheten och som är fastställda av högskolelagen (SFS, 1992). Dessa förhållningssätt är alltid under förhandling eftersom samhällsförhållanden såsom teknisk utveckling, politiska maktskiften och ideologiska trender påverkar den akademiska institutionens uppdrag (Barnett, 20I6). De centrala förhållningssätten inom akademin som varit gällande de senaste tvåhundra åren, och brukar benämnas "Det Humboldtska idealet", är att den akademiskt skolade kan anta ett kritiskt betraktelsesätt, beakta företeelser ur olika perspektiv samt analysera och förlita sig på vetenskapliga empiriska metoder (Sadurskis, 20I5). För lärarutbildningen gäller också att utbildningen är lagstadgad att vila både på vetenskaplig grund och på beprövad erfarenhet, något som studenterna i Säljös och Södlings studie (2006) uppfattade som två olika icke förenliga typer av kunskap, vilket kan bli problematiskt för lärarutbildaren.

Syftet med den här studien är att beskriva och analysera de nyblivna studenternas förhållningssätt gentemot sig själva och den kommande lärarprofessionen för att kunna lyfta fram vad som är viktigt att ta fasta på $i$ undervisningen.

Studiens specifika forskningsfrågor är:

- Vilka diskurser om den kommande lärarprofessionen framträder på de olika lärarutbildningarna?

- Vilka förhållningssätt artikuleras i diskurserna, och i vilken mån skiljer sig förhållningssätten åt mellan de olika lärarutbildningarna?

\section{FÖRHÅLLNINGSSÄTT SOM ETT POSITIONERINGSARBETE}

Förhållningssätt har studerats i samtal och texter på olika sätt och med delvis olika termer och begrepp, se t.ex. Chindamo, Allwood och Ahlsén (20I2) för en forskningsöversikt av detta. Eftersom vår teoretiska utgångspunkt är diskursanalytisk studerar vi förhållningssätten som positioneringar inom diskurser (Davies \& Harré, 1990).

Teorier kring positionering utgår ifrån att positioneringsarbetet utgörs av kommunikation i en diskursiv praktik (Davies \& Harré, 1990). Davies och Harré använder begreppet positionering inom ramen för ett poststrukturalistiskt paradigm som betonar det diskursiva fältet öppenhet snarare än diskursens konstituerande kraft. Det diskursiva fältets öppenhet handlar om att 
fältet erbjuder så många möjliga positioner att valmöjligheterna blir otaliga i varje nytt ögonblick (Laclau \& Mouffe, 2008; Hall, 2003). Positioneringar behöver inte vara medvetna utan kan snarare ses som tecken på rådande diskurser. Däremot är positioneringarna alltid meningsbärande. Davies och Harré (1990) skriver:

Participants may not be aware of their assumptions nor the power of the images to invoke particular ways of being and may simply regard their words 'the way one talks' on this sort of occasion. But the definition of the interaction being 'of this sort' and therefore one in which one speaks in this way, is to have made it into this sort of occasion (p. 265).

Flera studier tar upp lärar- och elevidentiteter och hur identiteter förhandlas i lärarutbildning och skola (Bayati, 20I4; Krantz, 2009; Brante, 2008), däremot inte de föreställningar studenterna bär med sig in i utbildningen. I denna studie undersöks hur lärarstudenter i början av lärarutbildningen konstruerar lärar- och elevidentiteter i öppna svar i en enkät. Studiens teoretiska utgångspunkt är att identitet artikuleras diskursivt. Centralt för vår förståelse av identitetsbegreppet är att identitetsformande utgörs av ett kontinuerligt positioneringsarbete. Mot bakgrund av studenternas berättelser om sig själva och sina förebilder framträder föreställningar om hur de ser, eller vill se, på sig själva som lärare liksom bilden av den kommande eleven. I studien undersöks emellertid även identitetspositioner som blir uteslutna i positioneringsarbetet (Laclau \& Mouffe, 2008, s. 157), det vill säga vad studenterna inte skriver om.

\section{METOD OCH MATERIAL}

Enkäter från förskollärarprogrammet, grundlärarprogrammen samt ämneslärarprogrammet samlades in under studenternas första veckor på utbildningen. Enkäternas primära syfte var att ge en bild av studentgruppens förhållande till sitt eget skrivande och läsande inför att börja en akademisk utbildning. Det fanns också frågor om valet att bli lärare för att vi skulle få en yrkesrelaterad referenspunkt till vad studenterna skrev om sina läs- och skrivvanor. Eftersom svaren på dessa frågor blev utförliga valde vi att analysera dem separat. Denna studie med fokus på de enkätfrågor som handlar om yrkesvalet kan sålunda betraktas som en spinoff-studie till den primära om läs- och skrivvanor.

Materialet består av 47I enkäter, som samlades in vid ett undervisningspass i början av utbildningen. Exemplen i resultatredovisningen åtföljs av numrering som dels visar vilket år studenten började sin utbildning, dels enkätnummer. Eftersom enkäter även samlades in för yrkeslärare, vilkas svar vi inte analyserat i den här studien, överstiger enkätnumreringen 47I. Lärarstudenterna fick veta att deltagande i undersökningen var frivilligt och helt anonymt liksom att materialet endast skulle användas i forsknings- och utbildningssyfte. Alla studenter valde att svara på enkäten, vilket innebär att vi inte har något bortfall. Vid insamlingstillfället hade vi inte tidigare mött studenterna, och även om vi vid senare tillfällen i utbildningen har träffat några av dem går svaren inte att härleda till specifika individer. Av tabellen nedan framgår att 165 enkätsvar från ämneslärarstudenterna insamlats, $\mathrm{I} 34$ från grundlärarprogramsstudenterna och $\mathrm{I} 72$ från förskollärarprogramsstudenterna. När det gäller kategorin grundlärarstudenter ingår inriktningarna F-3, 4-6 och fritidshem.

De svar vi studerar utgår ifrån följande frågor i enkäten:

- "Berätta något om dig själv och din väg till läraryrket! (Varför läser du till lärare? Är någon i familjen/vänkretsen lärare?)" 
Tabell I. Antal studenter från olika lärarprogram samt är för påbörjad utbildning

\begin{tabular}{|l|c|c|c|}
\hline År & Ämneslärarstudenter & Grundlärarstudenter & Förskollärarstudenter \\
\hline 2014 & $5 \mathrm{I}$ & - & 80 \\
\hline 2015 & 54 & 83 & 92 \\
\hline 2016 & 60 & $5 \mathrm{I}$ & - \\
\hline Summa & $\mathrm{I} 65$ & $\mathrm{I} 34$ & 172 \\
\hline
\end{tabular}

- "Har du under din egen skoltid känt dig sporrad och uppmuntrad att läsa vidare på högskola/universitet? (Kan du säga något om vad eller/och vem som uppmuntrat dig att plugga vidare?)"

För att kunna göra sökningar i materialet renskrev vi inledningsvis enkäterna. Därefter arbetade vi var för sig med svaren för att eftersträva interbedömarreliabilitet. Vid våra genomläsningar av enkätsvaren identifierade vi var för sig ett stort antal beskrivningar av både faktiska och föreställda lärare och elever. Det visade sig att studenterna använde lärar- och elevidentiteter som argument för sitt val att studera till lärare. Vi blev därför intresserade av vilka diskurser som artikulerades och i förlängningen även studenternas egna identitetspositioner.

Vårt analysfokus är inriktat på studenternas svar i enkäten även om frågor och svar tillsammans kan ses som ett skrivet samtal där diskurser konstrueras. Varje enskild students svar har analyserats som en semantisk enhet och kan kallas vår primära analysenhet, men positioneringen framträder på olika sätt i denna enhet, till exempel ordnivå, satsnivå eller hela svaret. Inom diskursanalys undersöks hur språket på olika sätt konstruerar betydelse. Det kan innebära att man studerar vad som impliceras eller vad som uttrycks explicit, vad som negeras, vilken modalitet som uttrycks, men även stilistiska aspekter för att utröna vilken betydelse som skapas (se t.ex. Chindamo, Allwood \& Ahlsén, 20I2; Gee, 20I4; Jaffe, 2009).

Vi har analyserat positionering vad gäller I) grad av säkerhet 2) grad av generalisering och 3) attityd (se Chindamo, Allwood \& Ahlsén, 20I2; Edwards, 1997). Ett exempel där olika grad av säkerhet framkommer är "Tycker de minsta barnen (I-5) är fascinerande. De är kloka och ger så mycket glädje. Är utrustad med ett stort tålamod och tror att jag passar bra till lärare." I detta svar är det verben som bär positioneringarna. Verbet "är" uttrycker den högsta graden av säkerhet medan verbet "tror" - något som är ovanligt i studenternas svar - uttrycker lägre grad av säkerhet. Ett exempel på generalisering framkommer i svaret: "Jag vill bli förskollärare för att jag älskar barn! Man får ut så mycket av att vara med barn." Pronomenet "jag" tillsammans med verbet vilja uttrycker här individens subjektiva uppfattning medan påföljande pronomen "man" visar att studenten betraktar det som en generell uppfattning, att alla får ut mycket av att vara med barn. Attityd kan implicera studentens känsla eller studentens värdering. Ett exempel på attityd som implicerar känsla framkommer i svaret "För att jag älskar barn! Barn är oslagbara!" där verbet älska förmedlar en känsla. Kommentaren "Barn är oslagbara" uttrycker en värdering, men notera också graden av säkerhet. Ett annat exempel på attityd som implicerar värdering framkommer i svaret "Jag läser till lärare på fritids för att jag vill ha ett lite 'annorlunda' jobb. Det sker mycket saker och man gör inte samma stillasittande sak varje dag." I detta svar visar negationen "inte" att stillasittande värderas som något negativt. I följande resultatredovisning lyfter vi fram diskurser och positioneringar som vi har funnit. 


\section{SOCIAL, PEDAGOGISK OCH PRAGMATISK DISKURS}

I lärarstudenternas enkätsvar om valet att gå en lärarutbildning framträder tre olika diskurser, en social som dominerar, en pedagogisk som endast är synlig i direkt anslutning till den sociala och en pragmatisk. Diskurserna relaterar till en innehållsmässig aspekt av läraruppdraget och artikuleras via studenternas beskrivningar av sig själva, läraryrket och sina kommande elever. Gemensamt för dessa tre innehållsmässiga diskurser är att beskrivningarna i hög grad framställer identiteter som förhållandevis förenklade, det vill säga som om identitet är något ensidigt och oföränderligt.

Som vi skrivit tidigare är det diskursiva fältet alltid öppet. Diskurser kan överlappa och gå in i varandra; de är alltså inte med nödvändighet varandra uteslutande (Laclau \& Mouffe, 2008). I följande avsnitt presenteras de diskurser och positioneringar som har framträtt i analysen samt hur de tar sig uttryck på de olika lärarprogrammen.

\section{Den sociala diskursen}

Den sociala diskursen artikuleras genom positioneringar gentemot lärarens sociala ansvar och relation till eleverna. Hos ämneslärarstudenterna uttrycks den sociala diskursen i termer av ett mentorskap som handlar om att leda de kommande eleverna genom en jobbig ungdomstid så att de utvecklas till "glada, starka, självständiga individer" (I6:548). Exempel på detta är:

- Jag vill ge mina framtida elever en bra start innan de släpps lösa i stora världen. (I5:I80)

- Möjligheten att lära ut och vägleda ungdomar i sitt liv, den sociala aspekten av att jobba med människor och försöka ge dem de bästa förutsättningarna för ett rikare liv. (I4:85)

- Det är inte alltid lätt med tonårsbarn, men det är så härligt att se när de verkligen har förstått något och det ger så mycket tillbaka ... (16:556)

- Jag vill utveckla ungdomar till glada, starka och självständiga individer. Proppa i dem fullt med bra och livsviktig kunskap och förebygga brott. (I6:548)

Det sista svaret kan också bedömas som tillhörande en pedagogisk diskurs eftersom den handlar om en, något tveksam men ändock, lärandestrategi. Det finns i detta svar inte någon motsättning mellan den sociala och den pedagogiska diskursen.

Den sociala diskursen artikuleras inte sällan mot bakgrund av upplevelser från den egna skoltiden. I vår studie framkommer att det inte endast är positiva erfarenheter av den egna skolgången som är en väg att hjälpa andra, utan även negativa skolerfarenheter som i några av följande exempel:

- När jag tittar tillbaka så sporrar min underbara svensklärare mig till att bli lika bra som hen. Samtidigt som de fruktansvärt dåliga sporrar mig till att bli bra. (I6:564)

- Jag minns min egen tid i skolan som jobbig. Hade problem med motivation och inläsning. En specifik lärare tände dock min glöd och påverkade mig så pass att jag minns det idag, över tio år senare. Det lockar mig, att hålla andras glöd levande, och påverka och utveckla andra människor. Därför vill jag vara lärare. (16:532)

- Jag har alltid haft dåliga lärare under mina skolår och vill ge eleverna en annan chans än det jag fått. (I6:535)

Ämneslärarstudenterna har övervägt yrken som polis, socialarbetare eller psykolog, men efter att ha prövat på läraryrket och tänkt igenom sitt yrkesval ytterligare har de fastnat för läraryrket, vilket uttrycks som ett i högre grad preventivt arbete än de andra. 
- Jag jobbar i kriminalvården annars. Jag inser när jag sitter där och pratar med grabbarna att många hade man kunnat fånga upp redan på skolan och hjälpa dem på rätt väg i livet. (16:553)

Den sociala diskursen handlar i detta fall om läraryrket som en förmåga att kunna stödja ungdomar, vilka uppfattas som sårbara. Eleverna beskrivs i generella ordalag som sårbara ungdomar, både i termer av sin osäkerhet och i termer av att de måste ta sig an uppdraget att anpassa sig till den stundande vuxenvärlden.

Motsvarande sociala diskurs artikuleras hos förskollärarstudenterna när de betonar att barn är naturliga, spontana och kreativa och att det är viktigt att värna dessa egenskaper. Lärarrollen handlar därmed om att skapa en tillåtande, trivsam arbetsplats/skola snarare än att säkerställa att eleverna förändras eller utvecklas. Om den sociala diskursen hos ämneslärarna tar sig uttryck i att hjälpa ungdomar att brygga över en "farlig" ungdomstid så artikuleras den hos förskollärarna utifrån förskolan som en plats för lek. Barn beskrivs som spontana och förskolläraren tillåts därför också att vara spontan och lite "sprallig". Bilden av "den lyckliga förskolläraren" träder fram i enkätsvaren liksom bilden av en arbetsplats där man trivs och får lov att ha roligt. Det sociala sker i mötet med barnet och på barnets nivå.

- Tycker de minsta barnen (I-5) är fascinerande. De är kloka och ger så mycket glädje. Är utrustad med ett stort tålamod och tror att jag passar bra till lärare. Min man är lärare i slöjd. (I4:33).

- För att jag älskar barn! Barn är oslagbara! Jag tycker om, ta hand om och pyssla rita måla det som barnen gör. De är fantastiska! (I5:293)

Grundlärarstudenterna skiljer sig på en punkt från ämneslärar- och förskollärarstudenterna: svaren är genomgående mycket kortare på alla frågor i enkäten. Studenterna svarar helt enkelt inte lika utförligt om sin väg till att söka lärarutbildning. För grundlärarstudenterna är den sociala diskursen inte lika framträdande som för ämneslärar- och förskollärarstudenterna. Den artikuleras tydligast på inriktningen mot fritidshem där den belyser samvaron med barnen utifrån att ha roligt tillsammans. I deras svar framträder också bilden av barnet som sårbart och i behov av skydd och trygghet. Lärarrollen blir därmed, förutom att ha roligt tillsammans med barnen, centrerad kring att hjälpa, stärka och vara en god förebild. Även fritidslärarna belyser att den kommande yrkesrollen möjliggör att ha roligt på jobbet.

- Jag som barn tyckte om att vara på fritids, att få vara ute och göra aktiviteter. Jag vill förmedla samma glädje till barn som idag går på fritids. (Fritids, 15:307)

- På fritids kan man vara lite som man vill, ingen som riktigt bryr sig på samma sätt. Man får leka av sig. (Fritids, I6:635).

- Vill hjälpa barnen att få en bra och rolig skolgång. (Fritids, I6:638)

Den pedagogiska diskursen

Den pedagogiska diskursen framträder i nästan alla fall antingen som komplement eller kontrast till den sociala. I följande exempel, som vi känner igen från den sociala diskursen, framträder den som komplement. Att proppa ungdomarna fulla med kunskap beskrivs som ett sätt att förebygga brott.

- Jag vill utveckla ungdomar till glada, starka och självständiga individer. Proppa i dem fullt med bra och livsviktig kunskap och förebygga brott. (I6:548). 


\section{Signild Risenfors och Elin Almér}

Ett exempel där den pedagogiska och den sociala diskursen står i kontrast framträder i följande citat där konjunktionen men signalerar kontrasten: "Jag älskar barn och har ett lekfullt men pedagogiskt sinne" (F-3, 16:596).

Hos ämneslärarstudenterna handlar den pedagogiska diskursen främst om läraryrket i vid mening, till exempel "Jag läser till lärare för att jag tycker jag är bra på att förklara” (I5:158). I ett fåtal fall presenteras ett skolämne. Följande exempel kan därmed representera en pedagogisk diskurs samtidigt som den sociala också representeras.

- Jag vill bli engelsklärare på gymnasiet för att dels syssla med ett ämne jag gillar dels för att kunna tillföra något positivt för mina framtida elever. Att kunna vägleda unga människor. (I4:99)

Hos förskollärarstudenterna artikuleras den pedagogiska diskursen som en önskan att lära ut och att se barn utvecklas:

- Gillar att arbeta med barn och följa deras utveckling. (I4:37)

- Har alltid tyckt mkt om barn gillar att hjälpa till och lära ut. (I4:45)

- Jag vill bli förskollärare för att jag älskar barn! Man får ut så mycket av att umgås och vara med barn. Att få vara med och lära dem allt man kan se polletten trilla ner när dom förstår, få vara med och leka på ett pedagogiskt sätt. Barn har alltid fångat mitt intresse. (15:217)

När det gäller grundlärarstudenterna skiljer sig artikulationerna åt mellan de tre inriktningarna. Studenterna med inriktning mot F-3 betonar att de vill följa barn i deras utveckling och lärande, medan endast en av grundlärarstudenterna med inriktning mot 4-6 belyser lärandet utifrån fokus på barnets lärande (sista exemplet nedan).

- Gillar att se personer/barn växa och utvecklas. (F-3, 15:336)

- Jag vill vara med och se barn utvecklas från grunden. (F-3, 16:590)

- Det bästa är när man ser elever lyckas. (F-3, I6:59I)

- Jag känner att jag har lätt för att inspirera barn och motivera dem inför en aktivitet. (4-6, I6:620)

Den pedagogiska diskursen framträder också i hur bemötande och ledarskap artikuleras, något som lyfts fram som värdefullt för den kommande yrkesrollen. Studenterna ger exempel på tidigare erfarenheter av engagemang i barnverksamhet och hur de har uppskattats för goda ledaregenskaper.

- Jag har alltid varit duktig på att förklara och uttrycka mig i kommunikation. (I5:I40)

- Jag har alltid fått bra respons när jag gärna hjälper till allt ifrån vänner till främlingar. Jag gillar även att hjälpa till varje gång jag kan. (I5:178)

- Jag fick väldigt positiv kritik angående mitt bemötande med eleverna. (I5:I43)

- Jag har alltid varit engagerad i olika verksamheter där jag fått leda och ta hand om barn. $(\mathrm{F}-3, \mathrm{I} 6: 590)$

Den pragmatiska diskursen

Den pragmatiska diskursen artikuleras utifrån att arbetsmarknaden idag kräver högskoleutbildning. Ibland skriver studenterna fram att de valt att påbörja en utbildning för att få arbeta med 
sådant de redan prövat på och trivts med, eller så skriver de att de valt att påbörja högskoleutbildning för att över huvud taget få ett jobb.

- Jag tycker det är jobbigt och tråkigt att plugga. Jag pluggar vidare för att få ett fast jobb, för det behöver man idag. (I4:77)

- Nej, jag var inte särskilt intresserad av att studera på högskola/universitet. Hade en väldigt jobbig skolgång/hemsituation. En dålig arbetsmarknad fick mig att tänka om. (I6:537)

Den pragmatiska diskursen artikuleras på ungefär samma sätt oavsett lärarprogram, men i minst utsträckning på ämneslärarprogrammet, som är det längsta av programmen (på Io eller II terminer). Den pragmatiska diskursen lyfts bland förskollärarstudenterna i termer av det behövs en utbildning för att få en tillsvidareanställning.

- Nej, men i dagens samhälle är det ett måste. Man får ingen anställning på en förskola utan utbildning. (I4:7I)

Även på grundlärarprogrammet, här fritidsinriktningen, artikuleras den pragmatiska diskursen.

- Man måste läsa vidare för att kunna få ett bra jobb och en fin examen. Utan utbildning är valmöjligheten inte lika stor och bred. (F-3, 16:606).

- Man vet att man måste läsa vidare för att få ett bra jobb. (Fritids, I6:637)

Den pragmatiska diskursen kan också ta sig uttryck i att läsa en utbildning som passar ens livssituation. Ofta anges aspekter från familjelivet; valet att bli förskollärare hänger ihop med att ha egna barn eller barn i släkten.

- Jag vill växa som människa. Jag vill få kunskap för att bli en bättre mamma till min femårige son. Jag tycker att barnet är det bästa man har för tillfället och att det är oerhört viktigt att de får bli bemötta på ett respektfullt och professionellt sätt så att personal måste ha utbildning för att undvika att göra fel. (15:255)

Även om, som i exemplet ovan, växandet som människa och åsikten att personal på förskolan bör ha utbildning, anges som ett skäl till att välja en lärarutbildning, är det ändå mammarollen som beskrivs som målet: "jag vill få kunskap för att bli en bättre mamma till min femårige son."

\section{Positioneringar hos lärarstudenter}

De tre diskurserna - den sociala, den pedagogiska och den pragmatiska - artikuleras genom lärar- och elevidentiteter, beskrivna med hög grad av säkerhet, med generaliseringar och ofta med stark attityd. Dessa språkliga drag samverkar till bilden av identiteter som förhållandevis ensidiga och oföränderliga. Den här positioneringen antar studenter på alla lärarprogrammen som exemplen i följande stycke visar, även om det är olika egenskaper som beskrivs som beständiga. Med hjälp av de exempel som vi har redovisat i avsnittet om diskurser tydliggör vi dessa positioneringar.

Studenterna uttrycker säkerhet, vilket framkommer i följande exempel där verbet "vara" visar identifikation mellan subjektet och de egenskaper eller förmågor som uttrycks: "Jag är social", 
"De [barnen] är kloka", "De är fantastiska", "Barn är oslagbara", "Jag har alltid varit duktig på att uttrycka mig i kommunikation" och "Jag är framåt som människa". I dessa uttryck framstår inte identitet som mångfacetterad utan som ensidig och oföränderlig. Generaliseringar förstärker denna bild. Uttryck som "Barn är kloka" eller "Barn är oslagbara" visar nämligen inte bara hög grad av säkerhet, utan är också generaliserande; alla barn beskrivs som likadana.

I relation till det egna valet att läsa lärarutbildning använder studenterna i hög grad det generaliserande "man" istället för "jag". Detta bidrar också till konstruktionen av identitet som förenklad. Studenterna uttrycker att inte endast de själva tycker och tänker på ett visst sätt, utan att det är en allmän tanke som i följande exempel: "Man får ut så mycket av att umgås med barn." Även i följande exempel framkommer tanken om att alla tycker som skribenten: "På fritids kan man vara lite som man vill, ingen som bryr sig. Man får leka av sig." Ordval som "man" och "ingen" synliggör en sådan generalisering. I den pragmatiska diskursen visar uttryck som "Man vet att man måste läsa vidare för att få ett bra jobb" att studenten ser det som allmän kunskap att det krävs utbildning för att få ett lärarjobb.

Attityder kopplade till känslor framkommer i uttalanden som "Jag älskar barn" och "barn är oslagbara", men även värderingar förekommer som i exemplet "Jag har rätt grundegenskaper till det [att bli lärare]". Det ges inget utrymme för förändring eller alternativa känslor och värderingar.

Positioneringarna blir delvis problematiska eftersom studenterna likställer beskrivningarna av sig själva med lärarprofessionen. Sålunda framträder en bild av att de redan har vad som behövs för att arbeta som lärare. Följande exempel visar detta:

- Jag läser till lärare för att jag tror att jag har rätt grundegenskaper till det. Jag tycker det är viktigt med rättvisa, jag har skinn på näsan, jag är framåt som människa och tycker om ämnet svenska men också engelska. Med rätt verktyg under dessa åren kommer jag att bli en BRA lärare. (20I4:89)

- Jag har ett stort hjärta, och är en samarbetsvillig människa som älskar att hjälpa andra människor. Jag vill hjälpa mina elever att flyga. (I5:I86)

- Jag läser till lärare för att jag tycker jag är bra på att förklara. (I5:158)

Det finns alltså en föreställning om att ha de rätta egenskaperna och därmed "vara menad för" att vara lärare.

- Jag har alltid gillat att lära ut. Det är något jag känner att jag är menad för. (F-3, I6:593)

Det är också problematiskt att de kommande eleverna beskrivs dels som om de alla vore likadana, dels att deras egenskaper framställs som oföränderliga. I lärarprofessionen behöver man möta elever som är olika och förstå att lärande förutsätter förändring.

\section{DISKUSSION}

Från vårt resultat vill vi lyfta fram de två aspekter som är mest centrala, och som dessutom är relevanta att ta hänsyn till i lärarutbildningen. Den första aspekten är att den sociala diskursen är hegemonisk framför den pedagogiska och den pragmatiska. De andra aspekten är att uttryck för grad av säkerhet, generaliseringar och i viss mån attityd samspelar till en positionering som kan ses som problematisk i mötet med en akademisk tradition. Det problematiska ligger i att förhållningssättet gentemot identiteter framstår som förenklat, som om identitet är ensidig eller 
oföränderlig. Den första aspekten kan sägas handla om diskursers innehåll och den andra aspekten kan sägas handla om hur studenterna förhåller sig till innehållet.

När det gäller den sociala diskursen visar resultatet att lärarstudenter kommer till lärarprogrammen med ett stort socialt patos. De vill hjälpa barn och ungdomar och relaterar många gånger till egna svårigheter i skolan. I vår studie framkom att studenter i hög grad "speglade sig i” sin egen skoltid och sina lärare som både positiva och negativa förebilder. Studenterna skriver bland annat fram omsorg om den enskilde elevens välbefinnande och att ingen ska utsättas för diskriminering.

Studenternas sociala patos kan ses som en relevant ingång till högskolestudierna eftersom den sociala diskursen så som den artikuleras i studenternas enkätsvar är i samklang med skolans och lärarutbildningens värdeuppdrag (jfr Sverige, Skolverket, 20I7). Den är också relevant för lärarutbildare att möta för att ta tillvara studenternas engagemang (Alm, Jungert $\&$ Thornberg, 20I4). Det är emellertid också viktigt att problematisera den sociala diskursen, dels för att studenterna uttrycker en alltför ensidig blick på identiteter, dels för att den pedagogiska diskursen inte ges motsvarande vikt. Den ensidiga bilden av identiteter kan ta sig uttryck i uttalanden som handlar om att ungdomar är sårbara och utsatta för faror och att läraridentiteten består av ett socialt mentorskap. Ett exempel på detta är då en student skriver att hen väljer läraryrket framför polisyrket för att kunna arbeta förebyggande med ungdomar istället för att ta hand om ungdomarna när problemen uppstått. Den pedagogiska utmaningen för lärarutbildare handlar sålunda om att värna om att studenterna även utvecklar en pedagogisk läraridentitet.

Det som vi definierar som den sociala diskursen kan också problematiseras i ljuset av att det är övervägande kvinnor som studerar på lärarprogrammen, speciellt eftersom studenterna ger uttryck för en förhållandevis ensidig hållning gentemot vilka de är. Det är problematiskt eftersom diskurser som artikulerar den känslomässiga anknytningen till barn sammanfaller med det som uppfattas som kvinnligt och som har ett lägre värde (Hirdman, 200I). Problematiken beskrivs ibland i termer av risken att mödrandet blir profession (Schatz-Oppenheimer \& Dvir, 20I3). Att vi noterat att motiven för att börja studera till lärare uttrycks på detta sätt hos studenterna synliggör vikten av att utmana denna diskurs som reproducerar läraryrket som primärt vårdande och därmed som en kvinnoangelägenhet.

De tre diskurserna framträder än tydligare mot bakgrund av vad som inte artikuleras i materialet. Artikulationen av en specifik diskurs förstärks av frånvaron av möjliga närliggande diskurser (Laclau \& Mouffe, 2008). För lärarstudenternas del hade det legat nära tillhands att relatera sitt yrkesval till aktuella mediedebatter om skolan. Skola är en av de mest omdebatterade politiska frågorna, och läraryrket lyfts som ett "krisyrke" med stora avhopp både från utbildningen och yrket. Ämneslärarstudenterna skriver om elevernas skoltid som en passage, men tar inte upp något om vad som finns på andra sidan passagen och i enkätsvaren nämns inte heller samhället eller mediedebatten om skolan. Resonemang kring kunskapssyn, hur man inspirerar till lärande eller vänder dåliga resultat till bra är i det närmaste osynliga. Ingen har nämnt någonting om sin syn på kunskap eller berört frågan om hur en lärare kan hantera komplexa klassrumssituationer. För universitetsläraren blir det sålunda angeläget att hitta en ingång där studenternas sociala diskurs kan bemötas och integreras i utbildningen utan att det sker på bekostnad av de delar av utbildningen som bär fram en pedagogisk diskurs och ett vetenskapligt förhållningssätt.

Den andra aspekten att ta hänsyn till i lärarutbildningen handlar om positioneringar inom diskurserna. Vår analys visar att studenternas positionering oberoende av program har liknande karaktär. Förhållningssätten förmedlar förhållandevis hög grad av säkerhet, generaliserande påståenden om identiteter och starka attityder. Oberoende av om detta förhållningssätt är en 
följd av den breddade rekryteringen, erfarenheter från tidigare skolformer eller rent av är ett uttryck för lärarstudenternas ålder blir det problematiskt i mötet med en akademisk tradition. Förmågan att argumentera, presentera en underbyggd åsikt och inta olika perspektiv är en grundläggande yrkeskunskap för lärare, och en förmåga som sammanfaller med ett vetenskapligt betraktelsesätt. Det vetenskapliga betraktelsesättet erbjuder studenterna ett specifikt sätt att relatera till sin omgivning, vilket återverkar på hela identiteten.

Eftersom studenternas positioneringar av sig själva i förhållandevis ensidiga beskrivningar tydligt framträder i början av deras utbildning ser vi som akademins kanske viktigaste uppdrag att i undervisning fokusera kritiskt tänkande och problematiseringsförmåga vad gäller den egna identiteten liksom den om elever.

\section{FÖRFATTARPRESENTATION}

Signild Risenfors har disputerat i pedagogik och universitetslektor i pedagogik vid Högskolan Väst. Hennes forskning handlar om ungdomars livstolkande och identitetsformande i olika utbildningskontexter. Hon undervisar bland annat på ämneslärarprogrammet.

Elin Almér har disputerat i lingvistik och universitetslektor i utbildningsvetenskap vid Högskolan Väst. Hennes forskning har fokus på olika aspekter av relationen mellan språk och identitet. Hon undervisar inom barn- och ungdomsvetenskap och på ämneslärarprogrammet.

\section{REFERENSER}

Alm, F., Jungert, T., \& Thornberg, R. (2014). Nyantagna lärarstudenters motiv, motivation, självtillit och akademiska engagemang [Elektronisk resurs]. Linköping: Institutionen för beteendevetenskap och lärande, Linköpings universitet.

Barnett, R. (2016). Det förnuftiga universitetet: skymtande möjligheter. I Tidskrift för politisk filosofi, årgång 20, nr. 3, 52-65.

Bayati, Z. (2014). "den Andre" i lärarutbildningen: en studie om den rasifierade svenska studentens villkor $i$ globaliseringens tid. Diss. Göteborg: Göteborgs universitet, 2014. Göteborg.

Bergmark, U., Lundström, S., Manderstedt, L., \& Palo, A. (2018). Why become a teacher?: Student teachers' perceptions of the teaching profession and motives for career choice. European Journal of Teacher Education, 41(3), 266-281.

Brante, G. (2008). Lärare av idag: om konstitutioneringen av identitet och roll. Diss. (sammanfattning) Lund: Lunds universitet, Malmö.

Brookhart, S. M., \& Freeman, D. J., (1992). Characteristics of Entering Teacher Candidates Review of Educational Research, Vol 62, Issue 1. http://doi.org/10.3102/00346543062001037

Calander, F. (red.) (2003). Nybörjare på Lärarprogrammet. Vilka är de? Vad vill de? Vad tycker de? [Elektronisk resurs]: En studie av nyantagna studenter höstterminen 2002 till lärarprogrammen i Gävle, Karlstad och Uppsala samt vid de danska folkeskolelererseminarierna Nørre Nissum och Zable /. Uppsala: Pedagogiska institutionen, Uppsala universitet.

Chindamo, M., Allwood, J., \& Ahlsén, E. (2012). Some Suggestions for the Study of Stance in Communication, 2012 International Conference on Privacy, Security, Risk and Trust and 2012 International Confernece on Social Computing. doi: 10.1109/SocialCom-PASSAT.2012.89

Davies, B., \& Harré, R. (1990). Position: The discursive constructions of selves. I Journal of the Theory of Social Behaviour, 20, s. 43-63.

Edwards, D. (1997). Discourse and cognition. London: Sage.

Gee, J.P. (2014). An introduction to discourse analysis: theory and method. (4. ed.) Abingdon, Oxon: Routledge.

Hall, S. (2003). Representation. London: Sage.

Hirdman, Y. (2001). Genus: om det stabilas föränderliga former. Stockholm: Liber. 
Holm, A. (2001). Vem söker sig till lärarutbildningen och varför?: en studie av blivande förskollärare och grundskollärare vid Högskolan i Borås. Borås: Högskolan i Borås, Inst. för pedagogik.

Jaffe, A. M. (red.) (2009). Stance: sociolinguistic perspectives. New York: Oxford University Press.

Krantz, J. (2009). Styrning och mening: anspråk på professionellt handlande i lärarutbildning och skola. Diss. Växjö: Växjö universitet.

Laclau, E., \& Mouffe, C. (2008). Hegemonin och den socialistiska strategin. Göteborg Glänta.

Lilliestam, A.-L. (2015). Nyblivna lärarstudenters syn på historia och historieundervisning. Nordidactica. Journal of humanities and social science education, vol. 4, s. 21-47.

Persson, M., (2009) Vägen till lärarutbildningen Motiv och föreställningar hos blivande gymnasielärare vid Växjö universitet. Praktiske grunde. Tidskrift for kultur og samfunnsvitenskab, no 4, s 59-76.

Sadurskis, A. (2015). Högre utbildning och forskningsanknytning. Universitetskanslersämbetet.

Schatz-Oppenheimer, O., \& Dvir, N. (2013). From ugly duckling to swan, stories of novice teachers. Teaching and Teacher Education, Vol. 37, s. 140-149. https://doi.org/10.1016/j.tate.2013.10.011.

SFS 1992:1434. Högskolelagen.

Sverige. Skolverket (2017). Läroplan för grundskolan, förskoleklassen och fritidshemmet 2011: reviderad 2017. [Stockholm]: Skolverket.

Säljö, R., \& Södling, M. (2006). Utbildningpå vetenskaplig grund: röster från fältet. Stockholm: Högskoleverket. Säll, E. (2000). Lärarrollens olika skepnader: estradör, regissör och illuminatör: en longitudinell studie av blivande lärares föreställningar. Diss. Uppsala: Univ. Uppsala.

Weiner, L. et al. (February, 1993). Choosing Teaching As a Career: Comparing Motivations of Harvard and Urban College Students. Paper presented at the Conference of the Eastern Educational Research Association, Cleerwater, FL.

Younger, M., Brindley, S., Pedder, D., \& Hagger, H (2004/2007). Starting points: student teachers' reasons for becoming teachers and their preconceptions of what this will mean, European Journal of Teacher Education , s 245-264. https://doi.org/10.1080/0261976042000290787 